\title{
Ultrastructural Study on Acibenzolar-S-Methyl-Induced Scab Resistance in Epidermal Pectin Layers of Japanese Pear Leaves
}

\author{
S. Jiang, P. Park, and H. Ishii
}

First and second authors: Graduate School of Science and Technology, Kobe University, Kobe, Hyogo 657-8501, Japan; third author: National Institute for Agro-Environmental Sciences, Tsukuba, Ibaraki 305-8604, Japan. Accepted for publication 14 January 2008.

\begin{abstract}
Jiang, S., Park, P., and Ishii, H. 2008. Ultrastructural study on acibenzolar-S-methyl-induced scab resistance in epidermal pectin layers of Japanese pear leaves. Phytopathology 98:585-591.

The infection behavior of Japanese pear scab pathogen Venturia nashicola race 1 was studied ultrastructurally in acibenzolar-S-methyl (ASM)pretreated susceptible Japanese pear (cv. Kousui) leaves to determine the mechanism of ASM-induced scab resistance. On ASM-pretreated leaf surfaces, the infection behavior (conidial germination and appressorial formation) was similar to that on distilled water (DW)-pretreated leaves prior to cuticle penetration by the pathogen. However, after penetration, differentiated behavior was found in epidermal pectin layers and middle

cated that fungal growth was suppressed in ASM-pretreated pear leaves. In the pectin layers of ASM- and DW-pretreated leaves, some hyphae showed morphological modifications, which were used as criteria to judge collapse of hyphal cells, including plasmolysis, necrotic cytoplasm, and cell wall destruction. More hyphae had collapsed in ASM-pretreated leaves than in DW-treated ones. In addition, the cell walls of collapsed hyphae broke into numerous fibrous and amorphous pieces, suggesting that ASM-induced scab resistance might be associated with cell-walldegrading enzymes from pear plants. In addition, results from morphometrical analysis suggested that the activity or production of pectindegrading enzyme from hyphae were inhibited by ASM application when compared with DW treatment.
\end{abstract} lamellae of the ASM-pretreated leaves. Subcuticular hyphae in epidermal pectin layers and middle lamellae of ASM-pretreated pear leaves were observed at lower frequency than in DW-treated leaves. The results indi-
Additional keywords: chitinase, PGIP.
Infection of plants with a necrotizing pathogen such as fungi, bacteria, or viruses can enhance the plant resistance against subsequent fungal, bacterial, or viral infection. This induced resistance can be restricted to areas of the first inoculation but may spread to other parts of the plant to establish systemic acquired resistance (SAR). For SAR to occur, the initial infection must result in formation of necrotic lesions, either as part of the hypersensitive response (HR) or as a symptom of disease $(22,33)$. SAR often is associated with the endogenous accumulation of salicylic acid (SA) $(26,32)$. SA is required for signal transduction $(13,23)$, leading to the occurrence of coordinated expression of pathogenesis-related (PR) proteins (35) and enhanced peroxidase activity (15). Exogenous application of SA and its synthetic analogs, such as 2,6-dichloroisonicotinic acid (INA) and acibenzolar-Smethyl (ASM), is also effective in inducing $\operatorname{SAR}(6,8,14$, $16,17,25,40)$.

In the pathosystem of Japanese pear with the scab pathogen Venturia nashicola, SAR induced by ASM has been described $(11,16,17)$. Ishii et al. $(16,17)$ reported that ASM showed high control efficacy against scab in susceptible pear leaves in field trials but had no marked inhibitory activity to spore germination, appressorial formation, and mycelial growth in vitro. These findings indicated that ASM suppressed scab disease by inducing resistance in susceptible pear plants but not by direct antimicrobial activity. In addition, in their molecular biological study, Faize et al. (11) reported that pretreatment of susceptible pear plants with ASM potentiated several lines of plant defense re-

Corresponding author: P. Park; E-mail address: ppark@kobe-u.ac.jp

doi:10.1094/PHYTO-98-5-0585

(C) 2008 The American Phytopathological Society sponse. One of them is the enhanced transcripts encoding polygalacturonase-inhibiting protein (PGIP), which is useful in the inactivation of polygalacturonases and causes the accumulation of oligogalacturonides in the plant apoplast which act as elicitors of a wide range of defense responses $(4,9,10)$. The promoted activity of peroxidase and several promoted $\mathrm{PR}$ proteins or their encoding genes such, as PR-1, chitinase, and PR-10, also were recorded in their study. In addition to these defense genes, ASM application also was able to induce phenyalanineammonia lyase and cell-wall-strengthening genes as well as signal transduction pathway genes in several plants $(2,6,21,27,28)$. However, the influences of these ASM-induced resistance responses of pear on the infection behavior of $V$. nashicola remain unclear at the ultrastructural level. We previously showed that scab resistance responses of resistant pear cultivars suppressed proliferation of the subcuticular hyphae in epidermal pectin layers, caused hyphal collapse, and inhibited pectin layer degradation by the scab pathogen $(20,30)$. In the present study, we attempted to examine whether similar phenomena occur in ASM-pretreated susceptible pear leaves. Therefore, we studied the distribution of $V$. nashicola hyphae and hyphal cell death in epidermal pectin layers of ASMpretreated susceptible pear leaves. In addition, we tried to monitor degraded areas of pectin layer with ultrastructural morphometry to evaluate the possible influence of the ASM-induced resistance on pectin degradation by the pathogen.

\section{MATERIALS AND METHODS}

Plant and pathogen. Cv. Kousui of Japanese pear (Pyrus pyrifolia Nakai var. culta Nakai), which is susceptible to V. nashicola race 1 (18), was used in this study. The conidia of $V$. nashicola race 1 collected directly from lesions were washed with distilled water by centrifugation and suspended in $0.1 \%$ sucrose 
solution. The conidial concentration was adjusted to $\approx 1 \times 10^{5}$ conidia $\mathrm{ml}^{-1}$.

ASM treatment and fungal inoculation. ASM (a gift from Syngenta Japan) treatment and fungal inoculation were performed as previously described, with slight modification (11). ASM $\left(100 \mu \mathrm{g} \mathrm{ml}^{-1}\right.$ ) or distilled water (DW) was applied by spraying on young pear leaves of the potted pear plants two times, 7 and 3 days before scab inoculation. The conidial suspension was dropped on the upper epidermis of the ASM- or DW-pretreated young leaves. After air drying, the inoculated plants were incubated in a moist chamber at $20^{\circ} \mathrm{C}$ for $48 \mathrm{~h}$, transferred to a phytotron, and maintained at $25^{\circ} \mathrm{C}$ for 1 to 7 days.

Electron microscopy. The inoculated leaves were detached from the potted plants 1, 2, 3, 5, and 7 days after inoculation. Inoculated portions of the leaves were trimmed into small pieces ( 3 by $3 \mathrm{~mm}$ ) with a razor blade. These leaf pieces were prefixed with $2.5 \%(\mathrm{vol} / \mathrm{vol})$ glutaraldehyde in $66.7 \mathrm{mM}$ phosphate buffer, $\mathrm{pH} 7.4$, at $4{ }^{\circ} \mathrm{C}$ overnight and postfixed with $1 \%$ buffered osmium tetroxide at room temperature for $1 \mathrm{~h}$. These pieces were dehydrated in a graded series of ethanol. Three pieces (from three different plants) were embedded with Spurr's resin (Nisshin EM, Tokyo) at each analyzed time point per treatment. Ultrathin sections were cut from these resin blocks with an ultramicrotome (Porter Blum MT-1, Norwalk, CT, USA) using a diamond knife (Diatome, Binene, Switzerland). The sections were stained with $4 \%$ uranyl acetate for $10 \mathrm{~min}$ and then with Sato's lead citrate for 10 min. Samples were observed with a Hitachi 7100 electron microscope (Hitachi, Hitachinaka, Japan).

Distribution of subcuticular hyphae in epidermal pectin layers of ASM- or DW-pretreated susceptible pear leaves. Jiang et al. (20) and Park et al. (30) reported that subcuticular hyphae of $V$. nashicola grew in the pectin layers of epidermal cell walls of scab-inoculated pear leaves but never invaded the epidermal cytoplasm regardless of susceptibility or resistance of the leaves, even on the seventh day after inoculation. In the present study, the distribution of the hyphae was examined ultrastructurally in the pectin layers of ASM- or DW-pretreated susceptible leaves to determine the effects of ASM application on fungal proliferation. The number of subcuticular hyphae was monitored in relation to the number of plant epidermal cells observed (hypha/epidermal cell ratio), and the percentage was calculated. At least 300 epidermal cells were observed in each block.

Frequency of collapsed subcuticular hyphae in epidermal pectin layers of ASM- or DW-pretreated susceptible pear leaves. The frequency of collapsed subcuticular hyphae was studied ultrastructurally in epidermal pectin layers of susceptible pear leaves pretreated with ASM or DW. Collapse of the hyphae was judged on the basis of plasmolysis and of necrotic cytoplasm with damaged organelles $(20,30)$. The number of collapsed hyphae was counted and the percentage of the total hyphae observed was calculated. At least 100 hyphae were observed in each block.

Ultrastructural morphometry on degraded areas of pectin layers near subcuticular hyphae in ASM- or DW-treated susceptible pear leaves. The sections were incubated for $30 \mathrm{~min}$ at $37^{\circ} \mathrm{C}$ with an alkaline bismuth stain $(0.05 \%$ sodium hydroxide, $0.02 \%$ potassium sodium tartrate, and $0.01 \%$ bismuth subnitrate) which is able to stain polysaccharides such as pectin (29). The degradation form of the pectin layers was evaluated on the basis of both the occurrence of electron-lucent pectin layer areas and the disappearance of dense materials in the pectin layers (20). At least 25 subcuticular hyphae chosen at random from three blocks were photographed at $\times 8,000$ at each analyzed time point per treatment. The negatives were printed at $\times 24,000$. The degraded areas of the pectin layer near the hyphae in the enlarged images were measured by a point-counting method $(1,36,37)$. A transparent point-counting sheet, marked with a grid consisting of a series of intersecting parallel lines (the distance between two lines is $5 \mathrm{~mm}$ ), was placed randomly over the micrographs. The num- ber of all cross-points lying on the digested pectin layer regions was recorded. A point represents the symbolized area of $0.043 \mu \mathrm{m}^{2}$ on the micrographs at $\times 24,000$. In addition to the measurement of the area, the lengths of plasma membranes of the hyphae were measured with a pen-type map-meter (Koizumi Sokki MFG., Co. Ltd., Japan) on the micrographs. The relative area of the degraded pectin layer near the hyphae was expressed as the degraded pectin layer area $\left(\mu \mathrm{m}^{2}\right)$ per $10 \mu \mathrm{m}$ of hyphal plasma membrane length.

Frequency of middle lamellae invaded by hyphae in ASMor DW-treated susceptible leaves. The subcuticular hyphae initiated invasion of the middle lamellae after their proliferation in pectin layers of susceptible pear leaves $(20,30)$. To understand the effect of ASM application on the invasion behavior after fungal pectin proliferation, we examined the frequency of middle lamellae invaded by hyphae in susceptible leaves pretreated with ASM or DW. The number of middle lamellae with hyphae was counted and the percentage of the total middle lamellae observed was calculated. At least 200 middle lamellae were observed in each block.

Statistical analysis. Mean values \pm standard error were calculated for data from three resin blocks containing three different plant samples at each analyzed time point per treatment. The values between ASM and DW treatments were compared by $t$ test using software SPSS 12.0 for Windows (SPSS Inc., Chicago).

\section{RESULTS}

Cell walls of upper epidermal cells in healthy susceptible Japanese pear leaves. The epidermal cell wall had three different layers: the first was the outermost cuticle layer, the second the electron-dense pectin-enriched layer, and the third the innermost electron-lucent cellulose layer. The pectin layer was continuous with the pectin-enriched middle lamellae between epidermal cells (Fig. 1).

Differential behavior of $V$. nashicola race 1 on surfaces of ASM- or DW-treated susceptible pear leaves. To study the effects of ASM pretreatment on the differential behavior of $V$. nashicola race 1 on the surfaces of susceptible leaves, we compared the behavior on ASM-pretreated leaves with that in DWpretreated ones. The fungal behavior was similar on ASM-treated and on DW-treated leaves. Conidia germinated to produce germ tubes on the surfaces of ASM- or DW-pretreated susceptible leaves. The tips of germ tubes changed into appressoria with infection sacs (Fig. 2). Penetration pegs emerged from the sacs to penetrate the cuticles. There were no differences in the frequency of conidial germination and appressorial formation (data not shown) between ASM and DW treatments. The germ tubes and appressoria were coated with an extracellular matrix (ECM) consisting of fibrillar and amorphous components (Fig. 2). ECM was positively stained with an alkaline bismuth.

Effects of ASM application on growth of subcuticular hyphae in epidermal pectin layers of susceptible Japanese pear leaves. After cuticle penetration by penetration pegs, thin pegs were transformed into thick subcuticular hyphae in epidermal pectin layers of susceptible leaves regardless of pretreatment with ASM or DW (Figs. 2 and 3). The hyphae grew horizontally in the pectin layers without invading the epidermal cytoplasm of both ASM- and DW-pretreated leaves, and proliferated much more with incubation time (Fig. 3). However, the ratio of hyphae to plant epidermal cells was significantly lower in the pectin layers of ASM-pretreated leaves than in those of DW-pretreated ones from the first day after inoculation.

Enhanced effects of ASM application on collapse of subcuticular hyphae of $V$. nashicola race 1 in epidermal pectin layers of susceptible Japanese pear leaves. In our previous work $(20,30)$, collapsed subcuticular hyphae were observed much more in epidermal pectin layers of scab-inoculated resistant pear leaves than in those of scab-inoculated susceptible ones. In the present 
work, we studied whether collapse of the hyphae was enhanced by ASM application. Plasmolysis and necrotic cytoplasm with damaged organelles were used as evidence of hyphal collapse (Fig. 4). The cell wall structure also was destroyed in most collapsed hyphae regardless of pretreatment with ASM or DW (Fig. 4B). In addition, the destroyed cell walls were not compact and had broken into many fibrous and amorphous pieces that were scattered in the spaces between plant cell walls and plasmolyzed fungal necrotic cytoplasm. The fibrous and amorphous pieces often were continuous with digested cell walls of the hyphae. (Fig. 4B).

The collapsed hyphae were observed from the third day after inoculation in epidermal pectin layers of both ASM- and DWtreated leaves. However, a significant increase in the frequency of collapsed hyphae was recorded in ASM-pretreated leaves on the seventh day after scab inoculation (Fig. 5).

Effects of ASM application on degraded areas of pectin layers near subcuticular hyphae in susceptible Japanese pear leaves. The areas of degraded pectin layer were measured by ultrastructural morphometry in pear leaves treated with ASM or DW and subsequently inoculated with conidia. During fungal proliferation in pectin layers, pectin layer degradation by the pathogen was seen in both ASM- and DW-pretreated pear leaves. When subcuticular hyphae grew in the epidermal pectin layers, the pectin layers near the hyphae became electron-dense at first, but the electron-dense regions seemed to be undigested at that time (Fig. 6A). Subsequently, the electron-dense regions changed into an electron-lucent form with fibrous debris (Fig. 6B). In some cases, the electron-lucent regions finally became empty. Both the electron-lucent regions and the empty regions in pectin

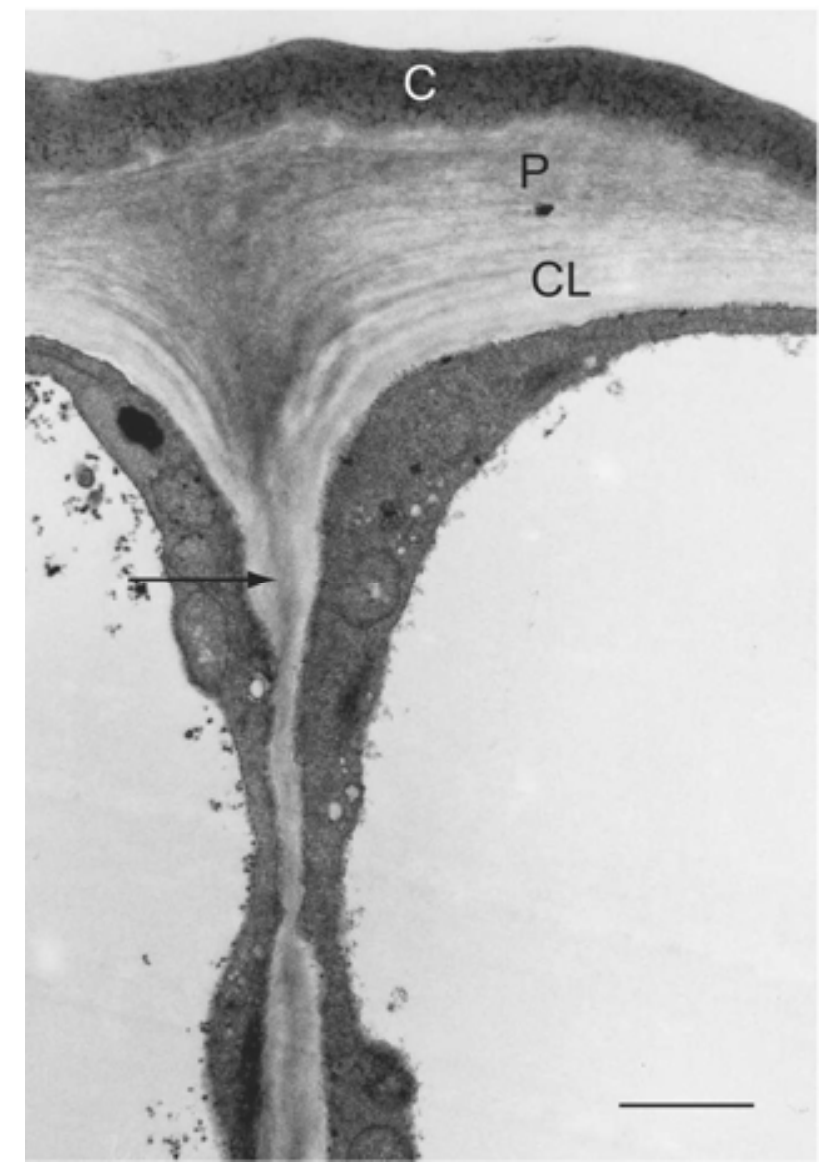

Fig. 1. Portions of two upper epidermal cells of healthy susceptible Japanese pear leaves showing three different cell wall layers and cytoplasm with cuticle layer $(\mathrm{C})$, pectin layer $(\mathrm{P})$, and cellulose layer (CL). The pectin is continuous with a middle lamella (arrow) between epidermal cells. Uranyl acetate and lead citrate staining. Bar $=1 \mu \mathrm{m}$. layers were judged to be the digested forms of pectin layers. Although the digested pectin layers usually were observed in leaves treated with ASM or DW from the second day after inoculation, the digested areas were significantly smaller in ASM-pretreated leaves than in DW-pretreated ones 5 and 7 days after inoculation (Fig. 7).

Effects of ASM application on invasion behavior of $V$. nashicola hyphae in middle lamellae of susceptible Japanese pear leaves. After the proliferation of subcuticular hyphae in epidermal pectin layers, some hyphae usually penetrated from the pectin

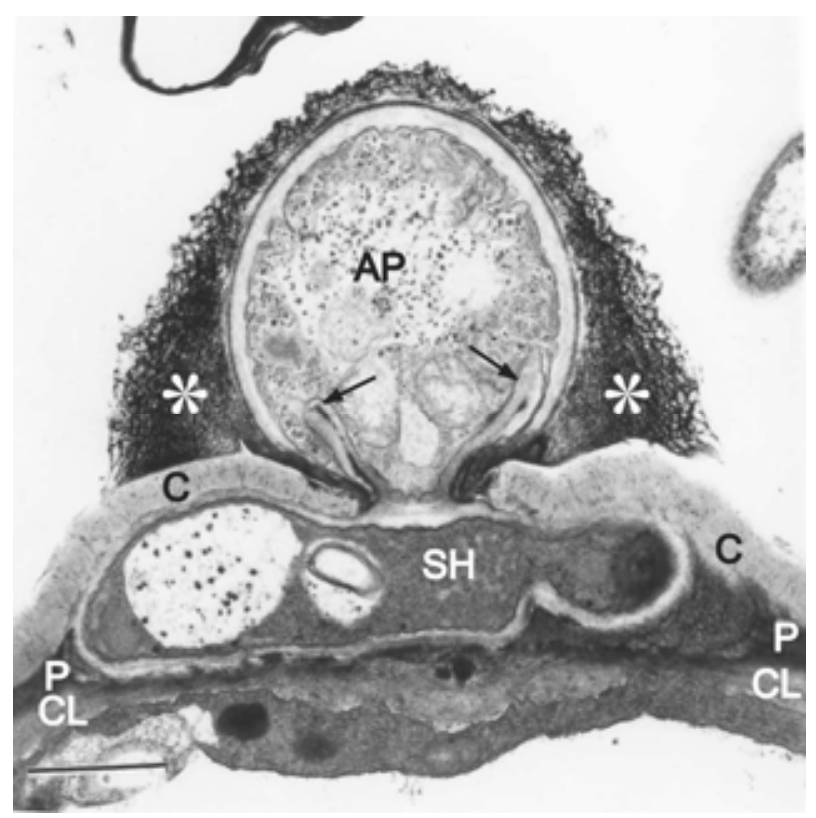

Fig. 2. An appressorium (AP) and a subcuticular hypha (SH) of Venturia nashicola race 1 in acibenzolar-S-methyl-treated susceptible Japanese pear leaves 2 days after inoculation with conidia. The appressorium had little cytoplasm compared with subcuticular hyphae and a cup-shaped infection sac (arrows) at the appressorial bottom. The penetration peg emerged from the sac to penetrate into the cuticle layer $(\mathrm{C})$ and then changed into thick subcuticular hyphae in the epidermal pectin layer (P), which was sandwiched between cuticles and cellulose layers (CL). The appressorium was covered with abundant extracellular matrix (asterisks). Alkaline bismuth staining. Bar $=1 \mu \mathrm{m}$.

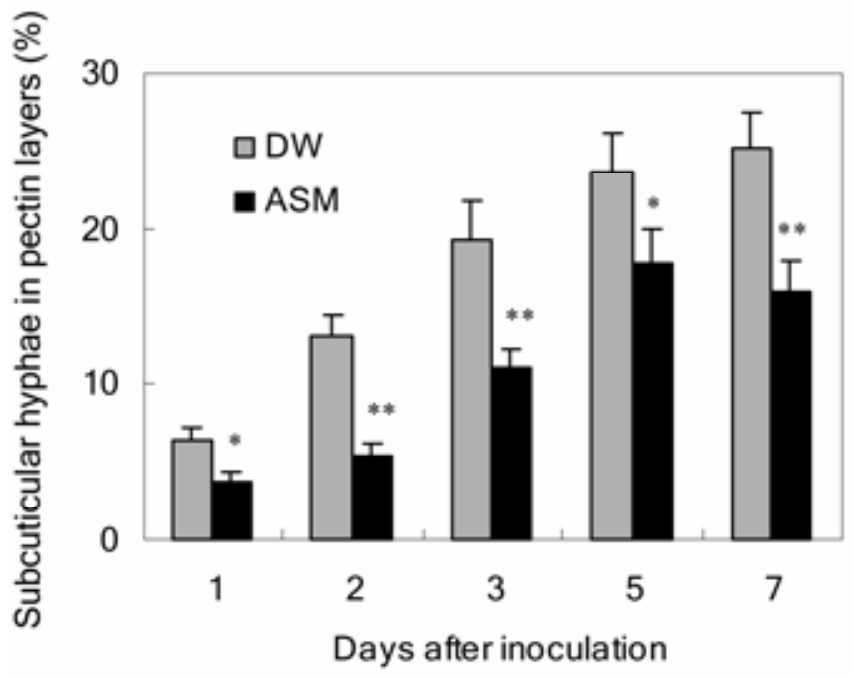

Fig. 3. Ratio of subcuticular hyphae of Venturia nashicola race 1 to epidermal cells of acibenzolar-S-methyl (ASM)- or distilled water (DW)-pretreated susceptible Japanese pear leaves 1, 2, 3, 5, and 7 days after inoculation with conidia. Vertical bars indicate standard errors. The values with asterisks are significantly different from DW treatments according to a $t$ test $(*$ and $* *=$ $P<0.05$ and 0.01 , respectively). 


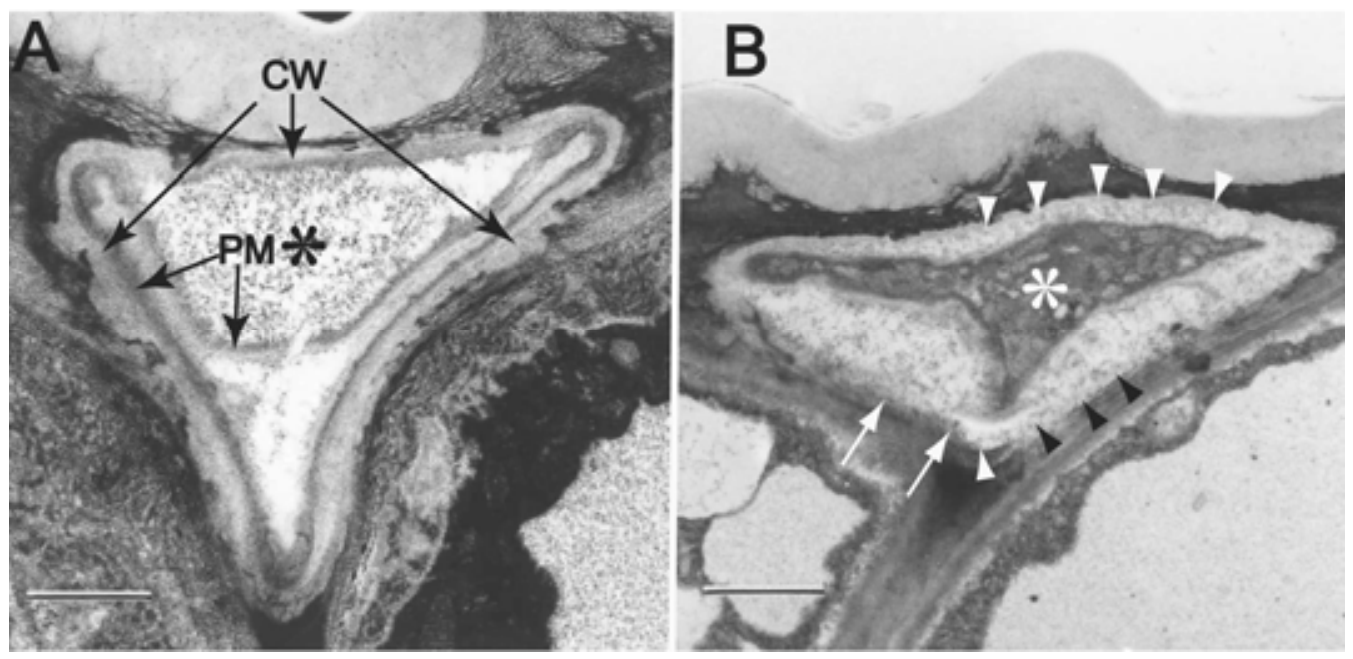

Fig. 4. Collapsed subcuticular hyphae of Venturia nashicola race 1 in epidermal pectin layers of acibenzolar-S-methyl (ASM)- or distilled water (DW)-treated susceptible Japanese pear leaves. A, The collapsed hypha in the epidermal pectin layer of DW-pretreated leaves 7 days after inoculation. Most of the fungal cell wall (CW) still remains intact, although plasmolyzed cytoplasm was seen. PM: plasma membrane. Alkaline bismuth staining. B, The collapsed hypha in ASMtreated leaves 7 days after inoculation. The cell wall structures were markedly destroyed (white and black arrowheads). The broken cell wall pieces were continuous with some intact parts of cell wall (white arrow). The asterisk indicates the necrotic cytoplasm of a plasmolyzed fungal cell. Alkaline bismuth staining. Bars $=1 \mu \mathrm{m}$.

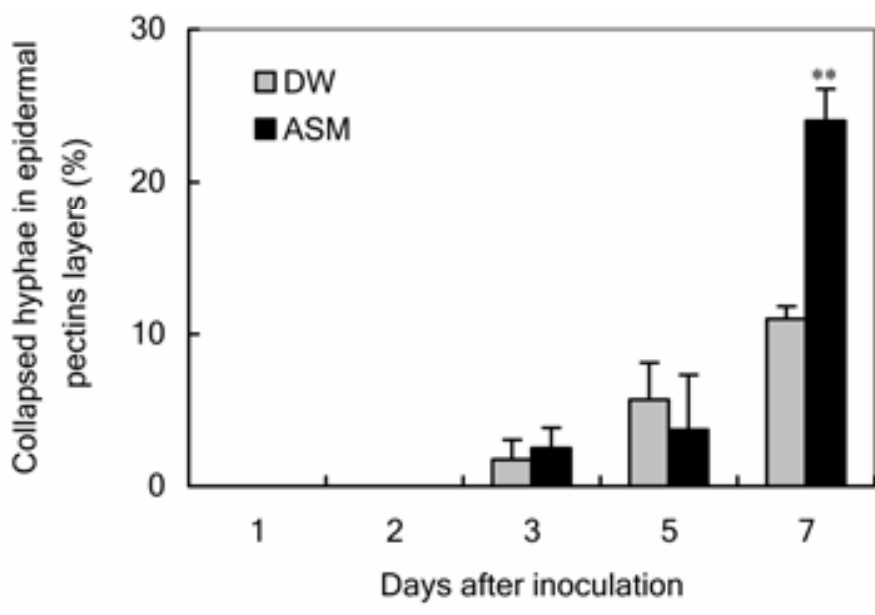

Fig. 5. Mean percentage of collapsed subcuticular hyphae of Venturia nashicola in epidermal pectin layers of acibenzolar-S-methyl (ASM)- or distilled water (DW)-treated susceptible Japanese pear leaves. Vertical bars on columns indicate standard errors. The values with asterisks are significantly different from DW treatments according to $t$ test $(*$ and $* *=P<0.05$ and 0.01 , respectively).

layers into pectin-enriched middle lamellae of DW-treated leaves and finally reached the intercellular spaces of mesophyll portions 3,5 , and 7 days after inoculation (Figs. 8 and 9). However, in most cases, fungal invasion to the middle lamellae was not found in ASM-treated leaves, except rarely on the third day after inoculation (Fig. 9).

\section{DISCUSSION}

We studied ultrastructurally the effects of ASM application on the infection behavior of $V$. nashicola race 1 in inoculated susceptible Japanese pear leaves before and after cuticle penetration.

Scab conidial germination and appressorial formation were not influenced by application of ASM on pear leaves and in vitro $(16,17)$. This ultrastructural study also showed that no differential behavior of the pathogen was found prior to cuticle penetration between ASM- and DW-treated leaves, indicating that resistance expression was not yet induced on the surfaces of ASM-pretreated pear leaves. However, resistance may be induced in pectin layers of ASM-pretreated and scab-postinoculated pear leaves. Three lines of evidence obtained from this work support this idea: (i) hyphal proliferation was suppressed in both the epidermal pectin layers and middle lamellae of ASM-pretreated leaves, (ii) hyphal collapse was frequent in the pectin layers of ASM-pretreated leaves, and (iii) degradation of pectin layers was inhibited in ASM-pretreated leaves.

After penetration, the penetration pegs succeeded in perforating the cuticles and developed into thick subcuticular hyphae in epidermal pectin layers of scab-inoculated susceptible leaves regardless of pretreatment with ASM or DW. However, the subcuticlar hyphae proliferated much more in the pectin layers of DW-treated leaves than in ASM-treated ones from the first day after inoculation. This indicated that hyphal growth may be suppressed by ASM-induced resistance responses in epidermal pectin layers. One of these responses might involve the expression of peroxidase (POX), which is enhanced by ASM pretreatment in Japanese pear (11) and cucumber leaves (8) after being challenged with fungal pathogens $V$. nashicola and Colletotrichum orbiculare, respectively. POX has been associated with several plant defense mechanisms, such as lignin biosynthesis, oxidative cross-linking of plant cell walls, and generation of reactive oxygen species (15). Park et al. (31) reported that $\mathrm{H}_{2} \mathrm{O}_{2}$-dependent lignification of cell walls was induced and lignification blocked anthracnose fungal growth in ASM-pretreated cucumber leaves. After fungal pectin proliferation, the hyphae of $V$. nashicola initiated invasion from the epidermal pectin layers into the middle lamellae of DWpretreated pear leaves from the third day after inoculation but they usually did not invade into the middle lamellae of ASM-pretreated leaves. The inhibited hyphal invasion to the middle lamellae probably resulted from ASM-induced suppression of hyphal growth in the pectin layers.

The hyphal collapse of $V$. nashicola was recognized by Jiang et al. (20) and Park et al. (30) during interaction of the pathogen with pear plants. Collapsed hyphae were determined by the following ultrastructural modifications: plasmolysis, occurrence of necrotic cytoplasm with damaged organelles, and degradation of fungal cell walls. The ultrastructural nature of collapsed hyphae was different from autolyzed hyphae which usually were seen at ends remote from the tip of vegetative hyphae (7). The necrotic cytoplasm was not seen in autolyzed hyphae, because aging hyphae became vacuolized and most cytoplasm with organelles has migrated toward the extending apex prior to hyphal autolysis. In 


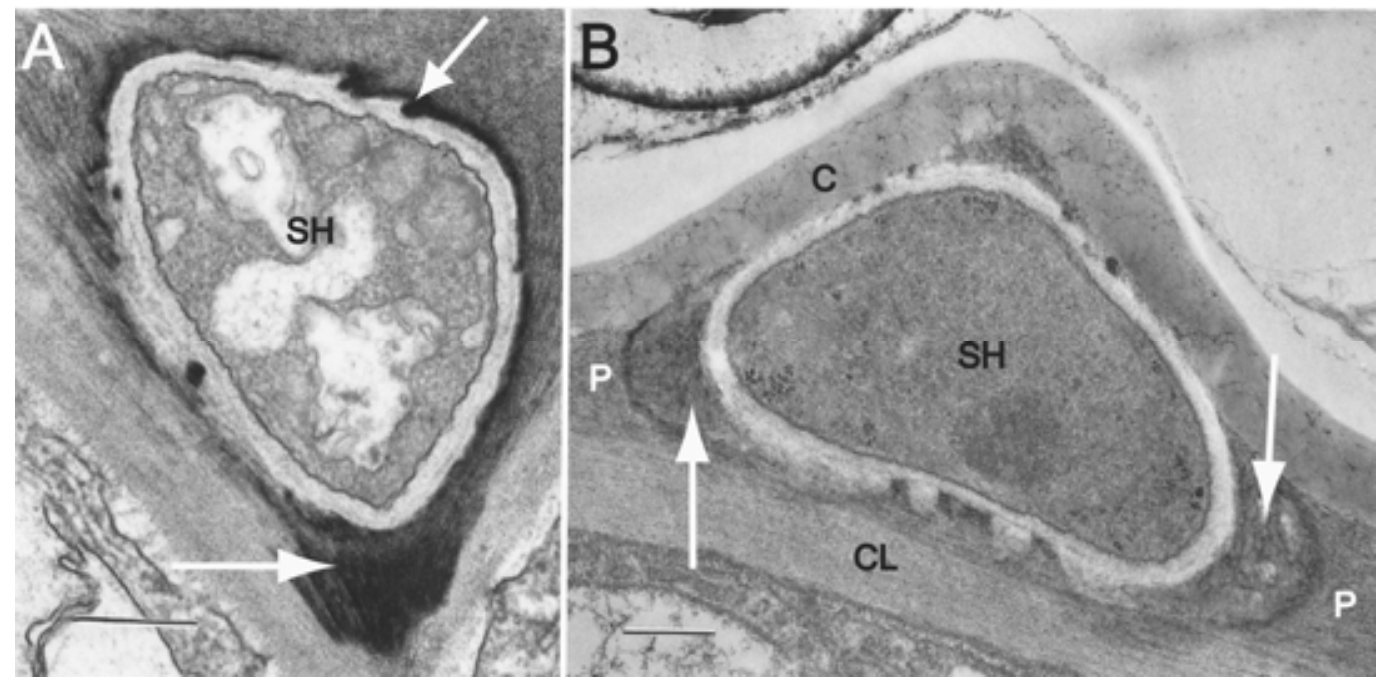

Fig. 6. Degraded epidermal pectins near subcuticular hyphae (SH) of Venturia nashicola in acibenzolar-S-methyl (ASM)- or distilled water (DW)-treated susceptible Japanese pear leaves, subsequently inoculated with conidia. The hyphae were located in the epidermal pectin layer (P) between cuticles (C) and cellulose layers (CL). A, Epidermal pectin layers touching subcuticular hyphae were electron-dense (white arrows) in DW-pretreated susceptible leaves 3 days after inoculation. B, Electron-dense pectin layers became electron-lucent amorphous areas with fibrous debris (white arrows) in ASM-pretreated leaves 5 days after inoculation. Alkaline bismuth staining. Bars $=0.5 \mu \mathrm{m}$.
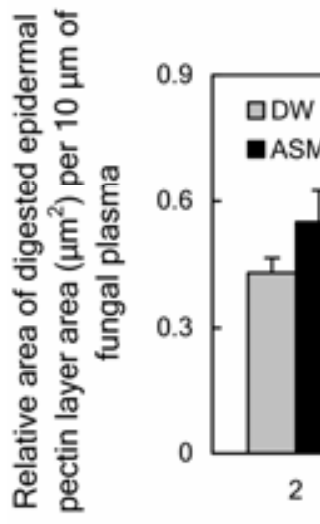

2

\section{DW}

\section{ASM}

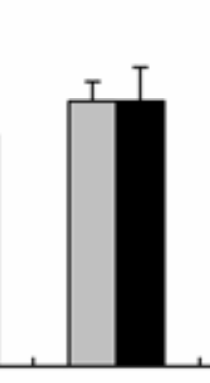

3

Days after inoculation

Fig. 7. Mean relative area of digested epidermal pectins in the vicinity of subcuticular hyphae of Venturia nashicola in acibenzolar-S-methyl (ASM)- or distilled water (DW)-treated susceptible Japanese pear leaves, subsequently inoculated with conidia. Vertical bars on columns indicate standard errors. Values with asterisks are significantly different from DW treatment according to a $t$ test ( $*$ and $* *=P<0.05$ and 0.01 , respectively).

addition, the cytoplasmic membranes of autolyzed hyphae were completely broken into a large volume of membrane fragments (34), whereas the cytoplasmic membranes of collapsed hyphae usually were broken only at local sites. Therefore, hyphal collapse was thought to be associated with scab resistance of pear plants. To evaluate the ASM-induced resistance response, the collapse of subcuticular hyphae was examined in epidermal pectin layers of ASM- and DW-pretreated susceptible leaves. The collapse was seen in both ASM and DW treatment from the third day after inoculation. However, collapsed hyphae were found at a significantly higher frequency at a later stage after inoculation in ASMpretreated leaves than in DW-pretreated ones. These results indicated that hyphal collapse may be enhanced by ASM-induced resistance responses in susceptible leaves.

The collapse of hyphae usually was accompanied by destruction of the fungal cell wall. Jiang et al. (20) suggested that the destruction might have resulted from the action of cell-walldegrading enzymes produced by pear leaves. Faize et al. (11) reported that transcript and translation of chitinase, a cell-walldegrading enzyme from plants, were promoted in ASM-pretreated and scab-postinoculated pear leaves. However, because chitin

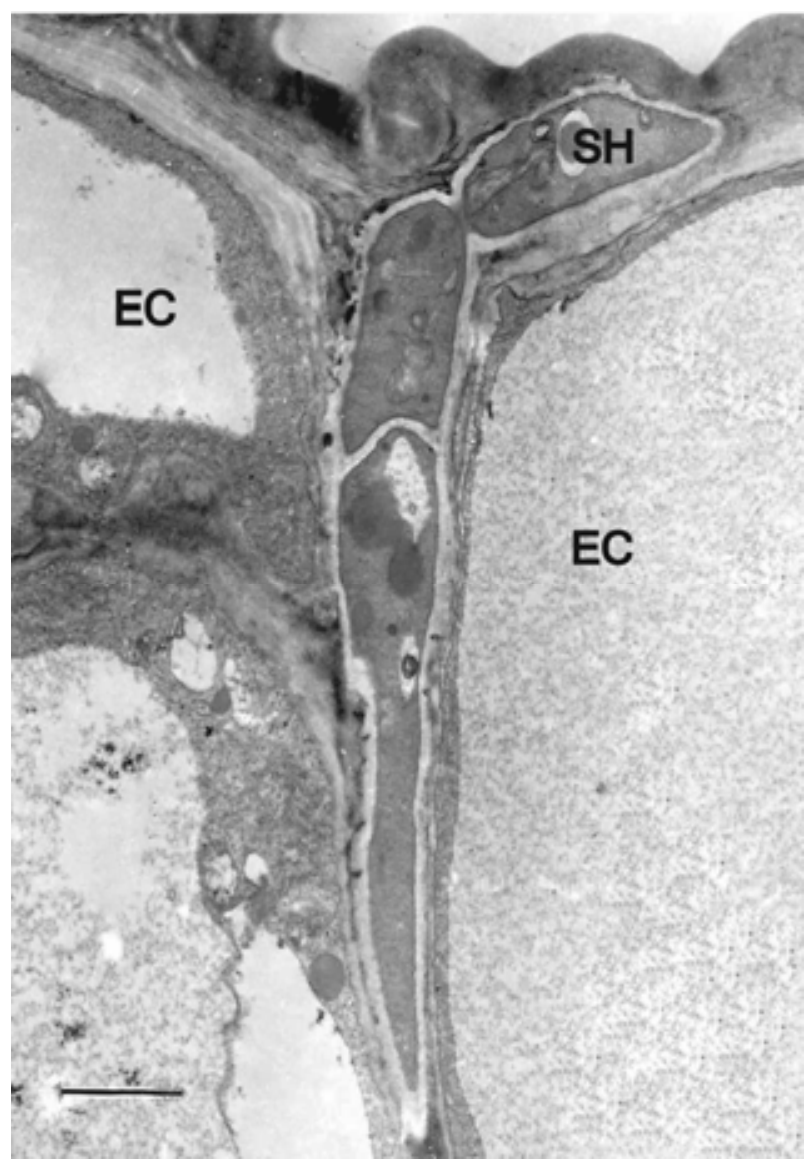

Fig. 8. Subcuticular hypha (SH) in a middle lamella between epidermal cells (EC) in distilled water-pretreated susceptible Japanese pear leaves 5 days after inoculation. $\mathrm{Bar}=1 \mu \mathrm{m}$.

cross-linked with glucan may be overlaid by other polysaccharides and protein layers in mature cell walls distant from the apex of hyphae $(38,39)$, the effectiveness of chitinases against fungi may be dependent on the simultaneous action of other cell-walldegrading enzymes or other antifungal substances rather than on its action alone $(5,24)$. In addition, Brisset et al. (3) reported that glucanases were activated in ASM-treated apple leaves and cor- 


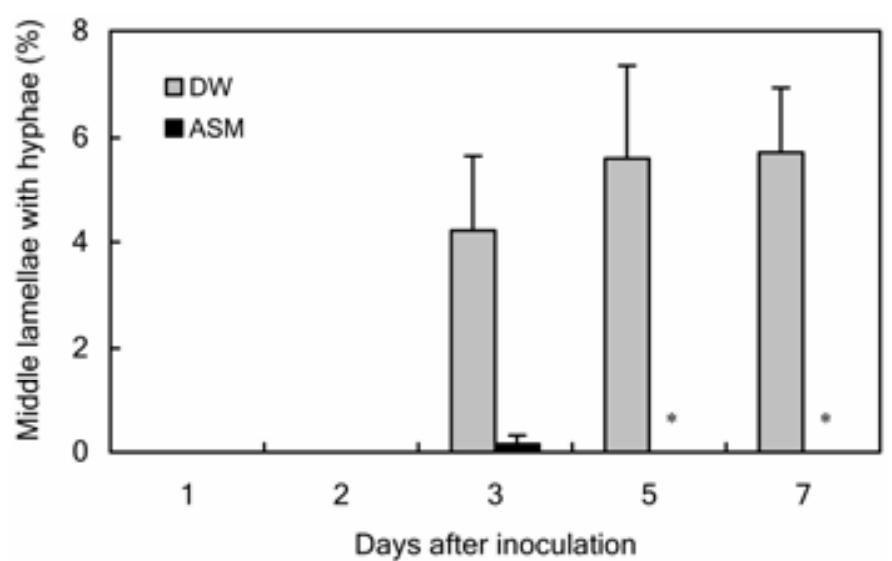

Fig. 9. Mean percentage of middle lamellae with hyphae of Venturia nashicola in acibenzolar-S-methyl (ASM)- or distilled water (DW)-treated susceptible Japanese pear leaves, subsequently inoculated with conidia. Vertical bars on columns indicate standard errors. The values with asterisks are significantly different from DW treatments according to a $t$ test $(*=P<0.05)$.

related with control of fire blight. Thus, we suggested that not only chitinase but also other cell-wall-degrading enzymes such as glucanases may be involved in the destruction of fungal cell walls in ASM-pretreated pear leaves postinoculated with scab fungus.

Park et al. (30) suggested that pectin degradation may be an important infection behavior for utilizing nutrients in the infection process of $V$. nashicola because the pathogen only grew in pectinenriched regions of cell walls in pear leaves. Subsequently, Isshiki et al. (19) purified the polygalacturonase (PG) from mycelia of the pear scab pathogens $V$. nashicola and $V$. pirina (the scab fungus of European pear). Recently, Jiang et al. (20) confirmed and ultrastructurally characterized the degradation of pectins and also measured the area of degraded pectin layers in pear leaves inoculated with scab fungus. Using the same method, we evaluated the effect of ASM application on the pectin degradation. The result showed that the subcuticular hyphae digested the pectin layers in DW-treated pear leaves much more than in ASMtreated ones. This indicated that the activity or production of pectin-degrading enzymes may be inhibited in ASM-treated leaves. The inhibition activity may be due, in part, to the expression of pectin-degrading enzyme-inhibitor proteins such as PGIP, which is able to inactivate PG produced by the hyphae, because enhancement of PGIP gene expression was recorded by Faize et al. (11) in ASM-pretreated pear leaves postinoculated with V. nashicola. Moreover, Faize et al. (12) described in another study that pgip gene transcript was higher and faster in nonhost European pear cv. Flemish Beauty and resistant Japanese pear cv. Kinchaku leaves inoculated with $V$. nashicola race 1 than in the susceptible leaves, and that the accumulation of PGIP protein also increased in these resistant cultivars. Thus, expression of PGIPs might be an important defense strategy against scab pathogens in pear leaves. However, to more precisely evaluate the role of PGIPs, the study of the histochemical location of PGIPs and PG must be carried out in the near future.

\section{ACKNOWLEDGMENTS}

We thank K. Ikeda (Graduate School of Science and Technology, Kobe University) for useful discussion.

\section{LITERATURE CITED}

1. Bellhouse, D. R. 1981. Area estimation by point-counting techniques. Biometrics 37:303-312.

2. Bovie, C., Ongena, M., Thonart, P., and Dommes, J. 2004. Cloning and expression analysis of cDNAs corresponding to genes activated in cucumber showing systemic acquired resistance after BTH treatment. BMC Plant Biol. 4:15.
3. Brisset, M. N., Cesbron, S., and Paulin, J. P. 2000. Acibenzolar-S-methyl induces the accumulation of defense-related enzymes in apple and protects from fire blight. Eur. J. Plant Pathol. 106:529-536.

4. Cervone, F., Hahn, M. G., De Lorenzo, G., Darvill, A., and Albersheim, P. 1989. Host-pathogen interactions: XXXIII. A plant protein converts a fungal pathogenesis factor into an elicitor of plant defense responses. Plant Physiol. 90:542-548.

5. Collings, D. B., Kragh, K. M., Mikkelsen, J. D., Nielsen, K. K., Rasmussen, U., and Vad K. 1993. Plant chitinase. Plant J. 3:31-40.

6. Cools, H. J., and Ishii, H. 2002. Pre-treatment of cucumber plants with acibenzolar-S-methyl systemically primes a phenylalanine ammonia lyase gene $(P A L 1)$ for enhanced expression upon attack with a pathogenic fungus. Physiol. Mol. Plant Pathol. 61:273-280.

7. Deacon, J. W. 1980. Morphology and ultrastructures. Page 3 in: Basic Microbiology, vol. 7. Introduction to Modern Mycology. J. W. Deacon, ed. Blackwell Scientific Publication, London.

8. Deepak, S. A., Ishii, H., and Park P. 2006. Acibenzolar-S-methyl primes cell wall strengthening genes and reactive oxygen species forming/scavenging enzymes in cucumber after fungal pathogen attack. Physiol. Mol. Plant Pathol. 69:52-61.

9. De Lorenzo, G., D'Ovidio, R., and Cervone, F. 2001. The role of polygalacturonase-inhibiting proteins (PGIPs) in defense against pathogenic fungi. Annu. Rev. Phytopathol. 39:313-335.

10. De Lorenzo, G., and Ferrari, S. 2002. Polygalacturonase-inhibiting proteins in defense against phytopathogenic fungi. Curr. Opin. Plant Biol. 5:295-299.

11. Faize, M., Faize, L., Koike, N., Ishizaka, M., and Ishii, H. 2004. Acibenzolar-S-methyl-induced resistance to Japanese pear scab is associated with potentiation of multiple defense responses. Phytopathology 94:604-612.

12. Faize, M., Sugiyama, T., Faize, L., and Ishii, H. 2003. Polygalacturonaseinhibiting protein (PGIP) from Japanese pear: Possible involvement in resistance against scab. Physiol. Mol. Plant Pathol. 63:319-327.

13. Gaffney, T., Friedrich, L., Vernooij, B., Negrotto, D., Nye, G., Uknes, S., Ward, E., Kessmann, H., and Ryals J. 1993. Requirement for salicylic acid for the induction of systemic acquired resistance. Science 261:754756.

14. Görlach, J., Volrath, S., Knauf-Beiter, G., Hengy, G., Beckhove, U., Kogel K. H., Oostendorp, M., Staub, T., Ward, E., Kessmann, H., and Ryals, J. 1996. Benzothiadiazole, a novel class of inducers of systemic acquired resistance, activates gene expression and disease resistance in wheat. Plant Cell 8:629-643.

15. Hammerschmidt, R., Nuckles, E. M., and Kuc, J. 1982. Association of enhanced peroxidase activity with induced systemic resistance of cucumber to Colletotrichum lagenarium. Physiol. Plant Pathol. 20:73-82.

16. Ishii, H., and Koike, N. 2003. Induction of scab resistance on Japanese pear by acibenzolar-S-methyl. (Abstr.) Jpn. J. Phytopathol. 69:39.

17. Ishii, H., Tomita, Y., Horio, T., Narusaka, Y., Nakazawa, Y., Nishimura, K., and Iwamoto, S. 1999. Induced resistance of acibenzolar-S-methyl (CGA 245704) to cucumber and Japanese pear diseases. Eur. J. Plant Pathol. 105:77-85.

18. Ishii, H., Udagawa, H., Nishimoto, S., Tsuda, T., and Nakashima, H. 1992. Scab resistance in pear species and cultivars. Acta Phytopathol. Entomol. Hung. 27:293-298.

19. Isshiki, A., Akimitsu, K., Ishii, H., and Yamamoto, H. 2000. Purification of polygalacturonases produced by the pear scab pathogens, Venturia nashicola and Venturia pirina. Physiol. Mol. Plant Pathol. 56:263-271.

20. Jiang, S., Park, P., and Ishii, H. 2007. Ultrastructural study on scab resistance expressed in epidermal pectin layers of pear leaves. J. Gen. Plant Pathol. 73:314-323.

21. Kohler, A., Schwindling, S., and Conrath, U. 2002. Benzothiadiazoleinduced priming for potentiated responses to pathogen infection, wounding, and infiltration of water into leaves requires the NPRI/NIM1 gene in Arabidopsis. Plant Physiol. 128:1046-1056.

22. Kuc, J. 2001. Concepts and direction of induced systemic resistance in plants and its application. Eur. J. Plant Pathol. 107:7-12.

23. Malamy, J., Carr, J. P., Klessig, D. F., and Raskin, I. 1990. Salicylic acid: a likely endogenous signal in the resistance response of tobacco to viral infection. Science 250:1002-1004.

24. Mauch, F., Mauch-Mani, B., and Boller, T. 1988. Antifungal hydrolases in pea tissue: II. Inhibition of fungal growth by combinations of chitinase and $\beta$-1,3-glucanase. Plant Physiol. 88: 936-942.

25. Métraux, J. P., Ahl-Goy, P., Staub, T., Speich, J., Steinemann, A., Ryals, J., and Ward, E. 1991. Induced resistance in cucumber in response to 2,6dichloroisonicotinic acid and pathogens. Pages 432-439 in: Advances in Molecular Genetics of Plant-Microbe Interactions. H. Hennecke and D. P. S Verma, eds. Kluwer Academic Publishers, Dordrecht, The Netherlands.

26. Métraux, J. P., Signer, H., Ryals, J., Ward, E., Wyss-Benz, M., Gaudin, J., Raschdorf, K., Schmid, E., Blum, W., and Inverardi, B. 1990. Increase in salicylic acid at the onset of systemic acquired resistance in cucumber. Science 250:1004-1006. 
27. Narusaka, Y., Narusaka, M., Horio, T., and Ishii, H. 1999. Induction of disease resistance in cucumber by acibenzolar-S-methyl and expression of resistance-related genes. Ann. Phytopathol. Soc. Jpn. 56:111-122.

28. Narusaka, Y., Narusaka, M., and Ishii, H. 2001. Searching by differential display for new genes implicated in induced disease resistance of cucumber treated with acibenzolar-S-methyl. J. Gen. Plant Pathol. 67:207-211.

29. Park, P., Fujiwara, T., and Fukutomi, M. 1977. Application of alkaline bismuth staining solution to Japanese pear leaf and fungal cells. J. Electron Microsc. 26:335-337.

30. Park, P., Ishii, H., Adachi, Y., Kanematsu, S., Ieki, H., and Umemoto, S. 2000. Infection behavior of Venturia nashicola, the cause of scab on Asian pears. Phytopathology 90:1209-1216.

31. Park, P., Kurihara, T., and Ishii, H. 2002. Ultrastructural analysis of induced systemic resistance in cucumber plants treated with acibenzolarS-methyl. (Abstr.) Jpn. J. Phytopathol. 68:162.

32. Rasmussen, J. B., Hammerschmidt, R., and Zook, M. N. 1991. Systemic induction of salicylic acid accumulation in cucumber after inoculation with Pseudomonas syringae pv. syringae. Plant Physiol. 97:1342-1347.

33. Ryals, J. A., Neuenschwander, U. H., Willits, M. G., Molina, A., Steiner,
H. Y., and Hunt, M. D. 1996. Systemic acquired resistance. Plant Cell 8:1809-1819.

34. Soina, V. S., and Agre, N. S. 1976. Fine structure of the vegetative and spore-forming hyphae of Micropolyspora fascifera (in Russian). Mikrobiologia 45:329-332.

35. Van Loon, L. C., and Van Strien, E. 1999. The families of pathogenesisrelated proteins, their activities, and comparative analysis of PR-1 type proteins. Physiol. Mol. Plant Pathol. 55:85-97.

36. Weibel, E. R. 1980. Theoretical foundations. Pages 1-348 in: Stereological Methods, vol. 2. E. R., Weibel, ed. Academic Press, London.

37. Weibel, E. R., Kistler, G. S., and Scherle, W. F. 1966. Practical stereological methods for morphometric cytology. J. Cell Biol. 30:23-38.

38. Wessels, J. G. H. 1986. Cell wall synthesis in apical hyphal growth. Int. Rev. Cytol. 104:37-79.

39. Wessels, J. G. H. 1988. A steady state model for apical wall growth in fungi. Acta Bot. Neerl. 37:3-16.

40. Ziadi, S., Poupard, P., Brisset, M. N., Paulin, J. P., and Simoneau, P. 2001. Characterization in apple leaves of two subclasses of PR-10 transcripts inducible by acibenzolar-S-methyl, a functional analogue of salicylic acid. Physiol. Mol. Plant Pathol. 59:33-43. 